\title{
A Comparative Study between Universal Eclectic Septoplasty and Cottle
}

\author{
Burak Karabulut $^{1}$ Serap Sahin-Onder ${ }^{1}$ \\ ${ }^{1}$ Department of Otolaryngology, Umraniye Eğitim ve Araştırma \\ Hastanesi, Umraniye, Istanbul, Turkey \\ Int Arch Otorhinolaryngol 2018;22:336.
}

The original article titled "A Comparative Study Between Universal Eclectic Septoplasty Technique and Cottle", published in October 2017, defended that universal eclectic septoplasty is a reliable surgical method. ${ }^{1}$

It was a great pleasure to read this article. However, a discrepancy was noticed. In the introduction section the authors stated that nasal obstruction was the $90^{\text {th }}$ (ninetieth) most frequent complaint reported at medical exams in the United States. Yet, there is no precise reference for this statement in the article.

Nasal obstruction is one of the leading complaints reported in rhinology practice and primary health care. ${ }^{2}$ Thus, we think it is a minor but important mistake to inaccurately rank this frequent symptom. Though its effect
Address for correspondence Burak Karabulut, Department of Otolaryngology, Umraniye Eğitim ve Araştırma Hastanesi, Elmalikent Mahallesi Adem Yavuz caddesi, No 1, Umraniye, Istanbul, 34764, Turkey (e-mail: kbbturk@yahoo.com).

on the reasoning of the article is negligible, we believe that this statement can easily misdirect and misinform readers.

Conflict of interest

The authors declare that they have no conflicts of interest to disclose.

\section{References}

1 Amaral Neto OFD, Mizoguchi FM, Freitas RDS, Maniglia JJ, Maniglia FF, Maniglia RF. A comparative study between universal eclectic septoplasty and cottle. Int Arch Otorhinolaryngol 2017; 21(03):281-285

2 Osborn JL, Sacks R. Chapter 2: Nasal obstruction. Am J Rhinol Allergy 2013;27(Suppl 1):S7-S8 received

November 22, 2017

accepted

February 27, 2018

published online

April 26, 2018
DOI https://doi.org/

10.1055/s-0038-1642606. ISSN 1809-9777.
Copyright (e 2018 by Thieme Revinter Publicações Ltda, Rio de Janeiro, Brazil
License terms

(c) (i) $\ominus$ (요 